\title{
EFISIENSI KERJA SAMA PENJAMINAN PEMBIAYAAN BANK SYARIAH DI LEMBAGA PENJAMINAN SYARIAH'
}

\author{
Ulfa Dwi Nurfajrina \\ Departemen Ekonomi Syariah-Fakultas Ekonomi dan Bisnis-Universitas Airlangga \\ Email: ulfanurfajri@gmail.com
}

\author{
Atina Shofawati \\ Departemen Ekonomi Syariah-Fakultas Ekonomi dan Bisnis-Universitas Airlangga \\ Email: atina-o@feb.unair.ac.id
}

\begin{abstract}
:
This research purpose to analyze of financing guarantee cooperation agreement between PT. Jamkrindo Syariah Surabaya Branch and Islamic Banks. This research also analyze the comparison of the efficiency level of Islamic Bank to measure the performance of each Sharia banks. Efficiency measurement is calculated using the Data Envelopment Analysis (DEA) method with an intermediation approach. The results showed that the implementation of such cooperation was not entirely in accordance with the DSN-MUI and OJK, while the results of efficiency level analysis of the four Islamic bank partners showed that there was one bank that had an efficiency value less than 1 (inefficiency), so that the performance was not optimal. Whereas other Sharia banks have achieved perfect efficiency of $100 \%$, which means they have achieved optimal performance.
\end{abstract}

Keywords: Efficiency, Data Envelopment Analysis (DEA), Financing Guarantee, Islamic Bank.

\section{PENDAHULUAN}

Bank syariah merupakan lembaga keuangan Islam yang memiliki fungsi sebagai lembaga intermediasi, yaitu menghimpun dana dari nasabah dalam bentuk simpanan dan menyalurkan dana tersebut melalui skim pembiayaan (Usanti, 2012). Pengelolaan dalam menyalurkan pembiayaan akan menentukan keberhasilan operasional perbankan syariah, karena pembiayaan merupakan kegiatan usaha yang dominan bagi perbankan syariah. (Ryandono dan Rani, 2018). Pengelolaan pembiayaan baik pembiayaan jual beli, pembiayaan bagi hasil, maupun jenis pembiayaan lainnya akan sangat mempengaruhi profitabilitas yang diterima bank syariah (Rahman dan
Rochmanika, 2012). Menurut Sofyan (2003), profitabilitas merupakan indikator yang paling tepat untuk mengukur kinerja suatu bank. Oleh karena itu, penyaluran pembiayaan merupakan bagian penting untuk mencapai kinerja yang baik bagi bank syariah.

Penyaluran pembiayaan bank syariah tidaklah terlepas dari risiko yang cukup besar yaitu risiko terjadinya moral hazard dan biaya transaksi tinggi. Risiko tersebut akan menurunkan pendapatan serta menggerogoti jumlah dana operasional dan likuiditas keuangan bank syariah, sehingga pada akhirnya akan menggoyahkan kesehatan bank syariah dan merugikan nasabah penyimpan/nasabah investor

\footnotetext{
${ }^{1}$ Jurnal ini merupakan bagian dari skripsi dari Ulfa Dwi Nurfajina, NIM: 041511433105, yang diuji pada 2 Agustus 2019.
} 
(Hermansyah, 2009: 72-73). Oleh karena itu, diperlukan lembaga penjaminan pembiayaan berdasarkan prinsip syariah untuk menjamin nasabah pembiayaan sehingga dapat melunasi kewajibannya sesuai dengan perjanjian pembiayaan yang telah disepakati.

Salah satu lembaga penjaminan yang dapat memberikan perlindungan terhadap pembiayaan bank syariah ialah PT. Penjaminan Jamkrindo Syariah. Selama memberikanjaminan suatu pembiayaan tidak bisa dipungkiri bahwa risiko yang dihadapi oleh PT. Penjaminan Jamkrindo Syariah lebih banyak bersifat moral risk seperti ketidaksanggupan membayar cicilan pinjaman dari nasabah debitur kepada bank syariah (pembiayaan macet).

Menurut Siamat (2005:175), pinjaman yang mengalami kesulitan pelunasan dapat disebabkan oleh faktor kesengajaan dan atau faktor eksternal suatu bank dalam pengelolaan dana yang disalurkan. Pembiayaan bermasalah tentu akan mempengaruhi sumber pendanaan bank syariah, salah satunya ialah pendapatan operasional dari pembiayaan. Semakin tinggi frekuensi pembiayaan bermasalah, menunjukkan kualitas pembiayaan bank syariah semakin buruk (Wibowo dan Syaichu, 2013).

Sumber pendanaan yang optimal merupakan bagian penting sebelum menyalurkan kembali dana yang dihimpun kepada pihak yang membutuhkan, hal ini dapat diukur melalui kinerja keuangan bank syariah. Oleh karena itu, PT. Penjaminan Jamkrindo Syariah perlu untuk mengukur kinerja mitra bank syariah.

Kinerja perbankan dapat diukur salah satunya dengan efisiensi, tingkat efisiensi yang dicapai merupakan cerminan dari kualitas kinerja yang baik (Sutawijaya dan Lestari, 2009). Efisiensi merupakan perbandingan antara output yang dihasilkan suatu organisasi dengan input yang digunakan dalam produksi output tersebut. Efisiensi merupakan gambaran kinerja suatu perbankan sekaligus menjadi faktor yang harus diperhatikan lembaga penjaminan untuk bertindak rasional dalam meminimumkan tigkat risiko yang dihadapi dalam menghadapi kegiatan operasinya.

Sutawijaya dan Lestari

(2009) mengemukakan dalam penelitiannya bahwa secara umum kondisi perbankan di Indonesia belum semuanya efisien. padahal kinerja bank syariah menjadi faktor penting yang harus diperhatikan apabila PT. Penjaminan Jamkrindo Syariah ingin melakukan ekspansi penjaminan pembiayaan kepada sejumlah perbankan syariah di Indonesia. Apabila dalam melakukan perjanjian kerja sama penjaminan pembiayaan PT. Penjaminan Jamkrindo Syariah tidak memperhatikan faktor efisiensi mitra bisnisnya, maka akan berdampak pada profitabilitas perusahaan (Nadia dkk, 2015). 
Nurfajina, et al/Jurnal Ekonomi Syariah Teori dan Terapan Vol. 6 No. 12 Desember 2019: 2435-2450; EFISIENSI KERJA SAMA PENJAMINAN PEMBIAYAAN BANK SYARIAH DI LEMBAGA PENJAMINAN SYARIAH

Menurut Sexton dkk (1986:73-105)

salah satu pendekatan untuk mengukur efisiensi yaitu pendekatan frontier, yang dibagi menjadi dua jenis, yaitu pendekatan frontier parametrik dan non parametrik. Pengukuran dalam penelitian ini menggunakan pendekatan frontier jenis non parametik dengan metode Data Envelopment Analysis (DEA).

Menurut Berger dan Humphrey (1997) dalam penelitian Zaenal dan Indri (2015), pendekatan intermediasi merupakan pendekatan yang banyak dipakai untuk mengukur efisiensi perbankan. Oleh karena itu, pendekatan intermediasi dinilai sesuai untuk mencerminkan karakteristik bank syariah sebagai financial intermediation yang menyalurkan dana dari pihak yang kelebihan dana kepada pihak yang membutuhkan dana. Penelitian ini memodifikasi variabel input output dari peneltian Yudistira (2003) dan Muharam dan Pusvitasari (2007), sehingga memilih DPK, biaya operasional lain, dan aktiva tetap sebagai variabel input. Sedangkan output-nya ialah total pembiayaan, total pendapatan operasional lain, dan aktiva lancar.

Berdasarkan latar belakang tersebur, maka dapat ditarik rumusan masalah yaitu bagaimana pelaksanaan kerja sama penjaminan pembiayaan bank syariah di PT. Penjaminan Jamkrindo Syariah cabang Surabaya dan bagaimana analisis efisiensi pelaksanaan kerja sama penjaminan pembiayaan bank syariah di PT. Penjaminan Jamkrindo Syariah cabang Surabaya dengan metode Data Envelopment Analysis (DEA).

\section{LANDASAN TEORI DAN PENGEMBANGAN HIPOTESIS}

Jaminan dalam ruang lingkup ekonomi Islam dikenal dengan konsep kafalah dan rahn, keduanya memiliki fungsi yang sama, yaitu menjadi jaminan bagi pelaksanaan kewajiban debitur untuk melunasi utangnya. Namun pada rahn yang menjadi jaminan adalah barang, sedangkan pada kafalah yang menjadi jaminan adalah orang atau badan hukum (Sjahdeini, 2014:379).

Secara istilah kafalah adalah menjamin tanggungan orang yang dijamin dalam melaksanakan hak yang wajib baik seketika maupun akan datang (Mardani, 2012:305). Sementara itu, menurut Bank Indonesia, kafalah adalah akad pemberian jaminan yang diberikan satu pihak kepada pihak lain di mana pemberi jaminan bertanggung jawab atas pembayarannya kembali suatu utang yang menjadi hak penerima jaminan (Sjahdeini, 2014:378).

Menurut Undang-Undang Republik Indonesia Nomor 1 Tahun 2016 Tentang Penjaminan pasal 1 poin pertama yang dimaksud dengan penjaminan syariah adalah kegiatan pemberian jaminan oleh penjamin atas pemenuhan kewajiban finansial terjamin kepada penerima jaminan berdasarkan prinsip syariah.Syirkah secara istilah, menurut ulama Malikiyah merupakan suatu 
Nurfajina, et al/Jurnal Ekonomi Syariah Teori dan Terapan Vol. 6 No. 12 Desember 2019: 2435-2450; EFISIENSI KERJA SAMA PENJAMINAN PEMBIAYAAN BANK SYARIAH DI LEMBAGA PENJAMINAN SYARIAH

perizinan untuk bertindak secara hukum bagi dua orang yang bekerja sama (Mujahidin, 2016:82).

$$
\text { Menurut Tanjung dan Devi }
$$
(2013:319-320) konsep efisiensi adalah kemampuan perusahaan dalam memanfaatkan sumber daya yang ada dengan biaya serendah mungkin dan menghasilkan output kekayaan sebanyakbanyaknya. Terdapat tiga macam efisiensi berdasarkan sudut pandang perusahaan, yaitu sebagai berikut (Tanjung dan Devi, 2013:320-321): (1) Technical Efficiency (Efisiensi Teknis) mencerminkan kemampuan perusahaan untuk mencapai output semaksimal mungkin dengan tingkat input yang tersedia. (2) Allocative Efficiency (Efisiensi Alokasi) mencerminkan kemampuan perusahaan dalam memaksimalkan input yang dimiliki dengan struktur harga dan teknologi, dan (3) Economic Efficiency (Efisiensi Ekonomis) merupakan gabungan dari efisiensi teknis dan efisiensi alokasi. Efisiensi ekonomis secara implisit merupakan konsep least cost production, yaitu pada tingkat output tertentu, suatu proses produksi dikatakan efisiensi secara ekonomis jika perusahaan tersebut menggunakan biaya di mana biaya per unit dari output tersebut adalah yang paling kecil.

Konsep efisiensi dalam pandangan Islam adalah kemampuan perusahaan untuk memperoleh output semaksimal mungkin dari sejumlah input tertentu dengan menggunakan cara-cara yang toyyib (baik). Sesuai dengan firman Allah
SWT dalam surat Al-Baqarah (2) ayat 168, yang artinya: "Hai sekalian manusia, makanlah yang halal lagi baik dari apa yang terdapat di bumi, dan janganlah kamu mengikuti langkah-langkah syaitan; Sesungguhnya syaitan itu adalah musuh yang nyata bagimu"

Konsep efisiensi dalam pandangan Islam sudah sejalan dengan prinsip syariah yang bertujuan untuk mencapai dan menjaga maqasid syariah (Kamaruddin, 2008). Islam menganjurkan efisiensi di setiap kegiatan yang dilakukan oleh umat Islam, termasuk kegiatan yang berlaku pada sistem perbankan. Oleh karena itu bank syariah pun perlu mementingkan efisiensi dalam proses operasional maupun produksi, agar mampu bersaing, berkembang dan mampu berperan lebih optimal dalam pembangunan nasional.

Data Envelopment Analysis (DEA) diperkenalkan pertama kali oleh Charnes, Cooper, dan Rhodes pada tahun 1978. Metode DEA adalah sebuah teknik aplikasi program linear yang mengukur efisiensi relatif dari Decision Making Unit (DMU) dan membandingkannya dengan DMU lain.Metode DEA memformulasikan DMU sebagai program linear fraksional untuk mencari solusi, apabila model tersebut ditransformasikan ke dalam program liniar dengan nilai bobot dari input dan output (Sutawijaya dan Lestari, 2009).Decision Making Unit (DMU) pada DEA mempresentasikan unit operasional (unit bisnis) yang akan dinilai. Pengukuran DEA merupakan analisis pengukuran 
berdasarkan analisis (process based analysis) yang berarti dapat diaplikasikan pada unit perusahaan apapun. Oleh karena itu, DMU dapat berupa organisasi atau apapun yang mampu merubah input (sumber daya) menjadi output (hasil). Istilah unit bisnis dalam DEA disamakan menjadi DMU (Tanjung dan Devi, 2013:328).

Nilai efisiensi yang dihasilkan oleh Data Envelopment Analysis (DEA) berkisar antara nol dan satu. Unit bisnis dikatakan efisien apabila memiliki nilai yang mendekati satu, sebaliknya jika nilai mendekati nol maka unit bisnis tersebut dianggap sebagai unit yang tidak efisien dibandingkan dengan unit-unit yang lain. Namun dalam pengertian unit bisnis yang efisien, bukan berarti memberikan output yang paling maksimum di antara sampel yang ada, tetapi memberikan gambaran best practice dari output di antara bank lainnya (Ascarya dan Yumanita, 2006).

\section{METODE PENELITIAN}

Pendekatan kualitatif deskriptif diterapkan karena permasalahan penelitian yang bersifat holistik. Di mana perjanjian kerja sama penjaminan pembiayaan yang dilakukan oleh bank syariah dengan PT. Penjaminan Jamkrindo Syariah dapat dipengaruhi oleh faktor tingkah laku manusia atau sistem perusahaan itu sendiri. Kemudian, dalam mengukur tingkat efisiensi bank syariah dalam pelaksanaan kerja sama tersebut, peneliti menggunakan Data Envelopment Analysis (DEA), yaitu alat evaluasi atas proses aktivitas di suatu sistem atau unit kerja. Hasil wawancara, observasi, dokumentasi, dan hasil olah data metode DEA akan dianalisis agar dapat diperoleh deskripsi mengenai efisiensi kerja sama penjaminan pembiayaan bank syariah di PT. Penjaminan Jamkrindo Syariah cabang Surabaya sehingga dapat mempermudah proses pengambilan kesimpulan.

Menurut Suprayogo dan Tobroni (2001:48), unit analisis adalah sesuatu yang berkaitan dengan fokus/komponen yang diteliti.Maka, unit analisis adalah bank-bank syariah yang merupakan mitra bisnis PT. Penjaminan Jamkrindo Syariah. Bank-bank syariah tersebut ialah:

a) PT. Bank Mandiri Syariah

b) PT. Bank BRISyariah

C) PT. Bank BNI Syariah

d) PT. Bank Jabar Banten Syariah

Sumber data primer merupakan data yang digali dari beberapa sumber utama yakni data yang diperoleh melalui penelitian lapangan mengenai pelaksanaan perjanjian kerja sama antara PT. Penjaminan Jamkrindo Syariah cabang Surabaya dengan Bank Syariah Mandiri, Bank BRlsyariah, Bank BNI Syraiah, dan Bank BJB Syariah dan wawancara langsung dengan beberapa pegawai PT. Penjaminan Jamkrindo Syariah.

Sedangkan data sekunder pada penelitian ini, yakni data yang didapatkan dari hasil penelitian terdahulu, jurnal, artikel, situs serta dokumen terkait yang dapat mendukung penelitian. Selain itu, laporan kevangan Bank Mandiri Syariah, 
Bank BRIsyariah, Bank BNI Syariah, dan Bank BJB Syariah termasuk data sekunder pada penelitian ini. Masing-masing laporan kevangan didapatkan dari website resmi tiap bank syariah.

Teknik pengambilan informan yang digunakan adalah purposive sampling. Di mana kriteria informan dalam penelitian ini adalah sebagai berikut: informan merupakan pegawai tetap yang sedang bekerja di PT. Penjaminan Jamkrindo Syariah kurang lebih selama tiga tahun, Informan memahami pelaksanaan kerja sama penjaminan pembiayaan bank syariah di PT. Penjaminan Jamkrindo Syariah cabang Surabaya, dan Informan memahami bidang keuangan yang berkaitan dengan pelaksanaan kerja sama penjaminan pembiayaan bank syariah di PT. Penjaminan Jamkrindo Syariah cabang Surabaya

Teknik trianggulasi yang digunakan dalam penelitian ini adalah trianggulasi sumber dan trianggulasi teknik. Trianggulasi sumber digunakan untuk mengecek keselarasan data hasil wawancara dengan beberapa sumber lain yang diperoleh dari informan mengenai pelaksanaan kerja sama penjaminan pembiayaan bank syariah di PT. Penjaminan Jamkrindo Syariah cabang Surabaya. Kemudian trianggulasi teknik dilakukan untuk mengecek keselarasan data yang diperoleh melalui berbagai teknik pengumpulan data yaitu hasil wawancara, observasi, dokumentasi, dan hasil olah data metode Data
Envelopment Analysis (DEA). Hasil pegecekan tersebut akan menghasilkan suatu kesimpulan dan kesepakatan dengan sumber-sumber yang telah ada.

Tahap pengolahan data yang diperoleh dari hasil wawancara, catatan lapangan, dan dokumentasi adalah menggunakan teori Miles dan Huberman yang dikemukakan oleh sugiyono (2017:484-492), yaitu meliputi: (1) Data Reduction (Reduksi Data), yaitu merangkum, memilih hal-hal yang pokok, memfokuskan pada hal-hal yang penting, mencari tema dan polanya dan membuang yang tidak perlu. (2) Data Display (penyajian Data), melalui penyajian data data akan lebih terorganisasi dan tersusun dalam pola hubungan, sehingga akan semakin mudah difahami. Penyajian data bisa dilakukan secara sistematis sesuai rumusan masalah dalam bentuk teks yang bersifat naratif singkat. (3) Conclucion Drawing/Verification, yaitu dengan menganalisis data yang telah diperoleh dari penelitian untuk memperoleh kesimpulan mengenai kebebnaran fakta yang ditemukan, yang akhirnya merupakan sebuah jawaban dari rumusan masalah.

Kemudian untuk mengukur tingkat efisiensi relatif bank syariah, penelitian ini menggunakan metode DEA dengan menggunakan pendekatan intermediasi dengan pengukuran input-outputoriented. Pengukuran dengan orientasi input menunjukkan sejumlah input dapat 
dikurangi secara proporsional tanpa mengubah jumlah output yang dihasilkan. Sedangkan orientasi output mengukur apabila sejumlah output dapat ditingkatkan secara proporsional tanpa mengubah jumlah input yang digunakan (Ascarya dan Yumanita, 2006).

Pengukuran inputoutputorientedpada penelitian ini dilakukan dengan dua asumsi skala pengukuran, yaitu asumsi skala Constant Return to Scale (CRS) dan Variable Return to Scale (VRS).Model CRS mencerminkan (perkalian dari) efisiensi teknis murni dan efisiensi skala, sedangkan model VRS mencerminkan efisiensi teknis murni saja (Ascarya dan Yumanita, 2006). Sehingga, efisiensi skala relatif adalah rasio dari model CRS dan modelVRS.

\section{HASIL DAN PEMBAHASAN}

Analisis Pelaksanaan Kerja Sama Penjaminan Pembiayaan Bank Syariah di PT. Penjaminan Jamkrindo Syariah cabang Surabaya

Secara bisnis-teknis PT. Penjaminan Jamkrindo Syariah bekerja sama dengan lembaga kevangan Islam, seperti bank syariah yang dituangkan dalam perjanjian kerja sama yang dibuat antara keduanya. Kerja sama tersebut dilakukan dengan adanya Perjanjian Kerja Sama (PKS) induk penjaminan secara tertulis dan resmi disetujui oleh kedua belah pihak. Posisi PT. Penjaminan Jamkrindo Syariah dalam perjanjian ini sebagai pihak ketiga atau penjamin, sehingga PT. Penjaminan Jamkrindo Syariah cabang Surabaya menawarkan lebih dulu kerja sama penjaminan pembiayaan kepada bank syariah.

Penawaran draft Perjanjian Kerja Sama (PKS) dengan bank syariah pun tidak langsung diberikan kepada bankbank yang belum menjalin kerja sama dengan PT. Penjaminan Jamkrindo Syariah cabang Surabaya, tetapi ada proses analisa terlebih dahulu di kantor pusat untuk melihat apakah calon mitra bank syariah layak diberikan penjaminan pembiayaan. Hasil wawancara yang dilakukan dengan ketiga informan sepakat menyebutkan bahwa hal yang perlu ditinjau sebelum memilih mitra bank syariah ialah laporan keuangannya.

Isi dari PKS setiap bank akan berbeda-beda sesuai dengan produk yang dijamin oleh PT. Penjaminan Jamkrindo Syariah cabang Surabaya. Perjanjian Kerja Sama yang diajukan pertama kali oleh PT. Penjaminan Jamkrindo Syariah cabang Surabaya kepada calon mitra bank syariah ialah berupa PKS induk penjaminan. Kemudian setelah kedua pihak menyetujui perjanjian tersebut, PT. Penjaminan Jamkrindo Syariah cabang Surabaya akan menerbitkan jenis PKS lainnya yang akan mengatur syarat dan ketentuan setiap produk pembiayaan bank syariah.

Penjaminan langsung merupakan penjaminan yang diberikan PT. Penjaminan Jamkrindo Syariah kepada terjamin guna mendapatkan jaminan untuk kebutuhan pembiayaan tanpa 
Nurfajina, et al/Jurnal Ekonomi Syariah Teori dan Terapan Vol. 6 No. 12 Desember 2019: 2435-2450; EFISIENSI KERJA SAMA PENJAMINAN PEMBIAYAAN BANK SYARIAH DI LEMBAGA PENJAMINAN SYARIAH

terlebih dahulu melalui pihak bank syariah. Sedangkan penjaminan tidak langsung merupakan penjaminan yang diberikan kepada terjamin (nasabah pembiayaan) oleh PT. Penjaminan Jamkrindo Syariah dengan melalui atau atas permintaan bank syariah lebih dulu. Di mana bank syariah telah melakukan perjanjian kerja sama penjaminan pembiayaan dengan PT. Penjaminan Jamkrido Syariah. Berikut adalah skim penjaminan langsung (CAC) dan penjaminan tidak langsung ( $C B C$ ).

Terdapat dua mekanisme pengajuan atas permohonan penjaminan pembiayaan bank syariah, baik pada penjaminan langsung maupun tidak langsung. Mekanisme tersebut tertera di dalam PKS antara bank syariah dan PT. Penjaminan Jamkrindo Syariah, yakni Conditional Automatic Cover (CAC) dan Case by Case (CBC). Apabila bank syariah mengajukan penjaminan pembiayaan dalam bentuk Conditional Automatic Cover (CAC) maka PT. Penjaminan Jamkrindo Syariah cabang Surabaya akan secara otomatis menyetujui memberikan penjaminan pembiayaan dengan tetap memperhatikan syarat dan ketentuan yang telah disepakati oleh kedua pihak di dalam PKS produk pembiayaan.

Sedangkan pada mekanisme Case by Case (CBC) PT. Penjaminan Jamkrindo syariah akan lebih dulu melakukan evaluasi kelayakan usaha nasabah pembiayaan atas setiap pengajuan penjaminan sebelum menerbitkan Surat Persetujuan Prinsip Kafalah (SP2K) sebagai bentuk persetujuan penjaminan. Pihak dari PT. Penjaminan Jamkrindo Syariah akan melakukan Penjaminan pembiayaan dilakukan selambat-lambatnya tujuh hari kerja terhitung sejak permohonan dan dokumen diterima lengkap oleh PT. Penjaminan Jamkrindo Syariah cabang Surabaya.

Ketika PT. Penjaminan Jamkrindo Syariah menyetujui untuk memberikan penjaminan yang dilakukan dengan cara CAC, maka PT. Penjaminan Jamkrindo Syariah cabang Surabaya akan langsung menerbitkan Sertifikat Kafalah (SK). Tetapi apabila PT. penjaminan Jamkrindo Syariah menyetujui penjaminan yang dilakukan dengan cara CBC, maka penerbitan Surat Persetujuan Prinsip Kafalah (SP2K) dilakukan terlebih dulu. Hal-hal yang tertera dalam SP2K ialah besarnya Imbal Jasa Kafalah (IJK) yang harus dibayarkan ke PT. Penjaminan Jamkrindo Syariah cabang Surabaya melalui rekening milik PT. Penjaminan Jamkrindo Syariah di masing-masing bank.

Secara resmi PT. Penjaminan Jamkrindo Syariah cabang Surabaya akan menjamin pembiayaan bank syariah sejak tanggal terbitnya SK.Selain dinyatakan berakhir sesuai dengan data dalam SK. Jangka waktu kerja sama penjaminan pembiayaan bank syariah dengan PT. Penjaminan Jamkrindo Syariah cabang Surabaya dapat pula berakhir apabila diterimanya perintah dari bank 
syariah untuk pembatalan penjaminan, manfaat penjaminan telah dibayar lunas, dan pelunasan pembiayaan dipercepat.

Bank syariah mempunyai hak untuk mengajukan ta'widh (klaim)/ganti kerugian apabila timbul hal-hal berikut selama pembiayaan: (1) Wanprestasi pembiayaan jatuh tempo, yaitu nasabah pembiayaan melakukan pelanggaran atau kegagalan dalam melaksanakan ketentuan kontrak atau perjanjian yang mengikat secara hukum yang mengakibatkan nasabah pembiayaan tidak dapat melaksanakan kewajibannya sampai dengan pembiayaan jatuh tempo. (2) Wanprestasi selama masa pembiayaan, yaitu wanprestasi yang diakibatkan karena menurunnya kualitas pembayaran angsuran. (3) Meninggal dunia, yaitu nasabah pembiayaan meninggal dunia dikarenakan sakit atau kecelakaan. (4) Gangguan usaha, yaitu nasabah pembiayaan mengalami risiko tertundanya pembayaran angsuran yang diakibatkan oleh tertanggungnya usaha yang disebabkan kebakaran dan atau banjir atas tempat usaha nasabah pembiayaan ataupun tempat sekitarnya.

Pencairan dana klaim dari PT. Penjaminan Jamkrindo Syariah cabang Surabaya tidak serta merta diberikan begitu saja setelah kelengkapan persyaratan berkas dipenuhi oleh bank syariah. Kinerja nasabah pembiayaan yang diajukan klaimnya perlu ditinjau lebih dulu oleh kepala bagian operasional PT. Penjaminan Jamkrindo Syariah cabang
Surabaya, setelah itu dilakukan analisis atas pengajuan klaim oleh kepala kantor cabang. Apabila diperlukan, PT. Penjaminan Jamkrindo Syariah cabang Surabaya akan melakukan kunjungan lapangan ke kantor bank syariah yang mengajukan permohonan klaim. Hasil laporan kunjungan lapangan akan dimanfaatkan sebagai bahan komite klaim atau divisi keuangan dan klaim di kantor pusat. Setelah itu, PT. Penjaminan Jamkrindo Syariah cabang Surabaya akan menerbitkan akseptasi beserta surat lainnya

Namun, ada beberapa perbedaan dalam hal penjaminan yang dilakukan secara CAC yang diatur dalam SOP klaim. Penjaminan yang dilakukan secara CAC tidak memerlukan adanya analisa kelayakan usaha, sehingga untuk bagian yang menangani klaim tidak perlu meminta pendapat kepada bagian operasional PT. Penjaminan Jamkrindo Syariah cabang Surabaya atas kinerja nasabah pembiayaan yang diajukan klaimnya. Analisis klaim pun dilakukan hanya dengan verifikasi dokumen dari bank syariah.

Kemudian klaim yang telah dibayarkan oleh PT. Penjaminan Jamkrindo Syariah cabang Surabaya kepada bank syariah tidak akan membebaskan nasabah pembiayaan dari kewajibannya melunasi pembiayaan dan bank syariah, atas nama PT. Penjaminan Jamkrindo Syariah, tetap melakukan penagihan kepada nasabah 
pembiayaan. Tercakup dalam SOP subrograsi, apabila PT. Penjaminan Jamkrindo Syariah telah melakukan pembayaran klaim maka hak tagih bank syariah kepada nasabah pembiayaan beralih menjadi hak tagih PT. Penjaminan Jamkrindo Syariah.

Praktik pelaksanaan kerja sama penjaminan pembiayaan dengan akad kafalah belum sepenuhnya sesuai dengan ketentuan dan ketetapan yang berlaku. Namun demikian penerapannya berlandaskan pada landasan syariah AlQur'an, yaitu landasan adanya penjaminan syariah. sesuai dengan firman Allah dalam surah Yusuf ayat 72 yang artinya: penyeru-penyeru itu berkata: "kami kehilangan piala raja, dan siapa yang dapat mengembalikannya akan memperoleh bahan makanan (seberat) beban unta dan aku menjamin terhadapnya." (QS. Yusuf (12):72).

Adapun syarat-syarat dokumen yang harus dipenuhi ataupun tata cara yang harus dilakukan, yang dimuat di dalam SOP Penyusunan Perjanjian Kerja Sama PT. Penjaminan Jamkrindo Syariah sudah sesuai dengan peraturan OJK No. 06/POJK.05/2014 tanggal 8 April 2014 tentang penyelenggaraan usaha lembaga penjaminan. Dilihat secara umum praktik pelaksanaan kerja sama penjaminan pembiayaan di PT. Penjaminan Jamkrindo Syariah cabang Surabaya sudah dilakukan dengan cukup baik, ini karena sudah sesuai dengan fatwa DSN-MUI No. 74/DSN-MUI/I/2009 tentang penjaminan syariah.

Hasil Perhitungan Efisiensi Bank Syariah Mandiri, Bank BNI Syariah, Bank BRIsyariah, dan Bank BJB syariah, dengan Data Envelopment Analysis (DEA)

Menurut Tanjung dan Devi (2013:320) perbankan syariah dinilai efisien jika perusahaan mampu memanfaatkan sumber daya (input) yang ada dengan biaya serendah mungkin dan menghasilkan output sebanyakbanyaknya. Perhitungan efisiensi penelitian ini menggunakan metode Data Envelopment Analysis (DEA) yang diolah dengan software MaxDEA 7 Basic dengan input-output orientation, serta asumsi Constant Return to Scale (CRS) dan Variable Return to Scale (VRS), dengan pendekatan intermediasi.

$$
\text { Hasil perhitungan efisiensi }
$$
menunjukkan mitra Bank Syariah di PT. Penjaminan Jamkrindo Syariah cabang Surabaya pada tahun 2018. Hasil menunjukkan bahwa terdapat DMU yang memiliki score kurang dari 1 pada model CRS dengan orientasi input-output, yaitu Bank BNI Syariah dengan score efisiensi 0,93. Begitu pula dengan perhitungan pada model VRS yang menunjukkan score efisiensi kurang dari 1 yaitu sebesar 0,94 untuk orientasi input dan 0,93 untuk orientasi output.Nilai tersebut mengartikan bahwa pada model CRS dan VRS dengan orientasi input-output, Bank BNI Syariah belum mencapai efisiensi baik secara teknis (CRS) maupun skala (VRS). Oleh 
Nurfajina, et al/Jurnal Ekonomi Syariah Teori dan Terapan Vol. 6 No. 12 Desember 2019: 2435-2450; EFISIENSI KERJA SAMA PENJAMINAN PEMBIAYAAN BANK SYARIAH DI LEMBAGA PENJAMINAN SYARIAH

karena itu, Bank BNI Syariah perlu meningkatkan lagi score efisiensi model CRS sebesar $7 \%$ serta score efisiensi VRS sebesar $6 \%$ yang berorientasi input dan $7 \%$ pada orientasi output.

Sedangkan ketiga DMU bank syariah lainnya seperti Bank Syariah Mandiri, Bank BRISyariah, dan BJB Syariah menunjukkan score efisien 1 pada model CRS dan VRS dengan orientasi inputoutput. Nilai 1 pada model CRS yang mengartikan bahwa ketiga bank syariah tersebut telah efisien secara teknis dan skala. Begitu pula dengan nilai 1 pada model VRS, efisien secara teknis murni telah dicapai oleh ketiga bank syariah tersebut. Maka dapat dikatakan bahwa efisiensi ketiga bank syariah yang pada perhitungan ini telah mencapai efisiensi sempurna yakni $100 \%$ dan tidak perlu ditingkatkan lagi.

Masing-masing DMU mempunyai benchmark atau acuan efisiensi, karena DEA merupakan analisa yang membandingkan efisiensi antar DMU yang diteliti. Sehingga DMU yang tidak efisien, akan mengacu pada DMU yang lebih efisien (Wahyuni, 2016). Benchmark sebuah DMU yang efisien akan mengacu pada DMU itu sendiri,karena DMU tersebut tidak perlu mengacu pada DMU lain untuk menjadi efisien seperti pada semua hasil perhitungan efisiensi Bank Syariah Mandiri, Bank BRISyariah, dan BJB Syariah. Namun, DMU yang tidak efisien menunjukkan benchmark yang mengacu pada DMU lain seperti pada hasil perhitungan efisiensi
Bank BNI Syariah yang harus melakukan benchmark terhadap bank-bank yang menjadi acuan dalam melakukan benchmark.

Setiap bank syariah yang menjadi acuan Bank BNI Syariah memiliki shadow price. Shadow price tersebut berfungsi sebagai angka pengganda (multiplier) yang digunakan sebagai dasar untuk menyesuaikan input dan output Bank BNI Syariah agar menjadi efisien (Nadia dkk, 2015). Hasil perhitungan efisiensi model CRS pada Bank BNI Syariah menunjukkan benchmark mengacu pada Bank Syariah Mandiri dan Bank BRISyariah. Pada orientasi input, masing-masing shadow price sebesar $23 \%$ dan $43 \%$, sementara untuk yang berorientasi output sebesar $24 \%$ dan $46 \%$. Kemudian pada model VRS benchmark mengacu pada ketiga bank lainnya, di mana pada orientasi input, shadow price Bank Syariah Mandiri sebesar 11\%, Bank BRISyariah sebesar $76 \%$, dan BJB Syariah sebesar $11 \%$. Sedangkan yang berorientasi output masing-masing sebesar $14 \%, 75 \%$, dan $10 \%$.

Pengukuran efisiensi secara
general harus diikuti dengan
pengetahuan mengenai variabel apa saja yang menyebabkan inefisiensi suatu DMU, dalam hal ini adalah Bank BNI Syariah. Hal ini diperlukan untuk mengetahui jenis variabel apa yang perlu dikurangi dan/atau ditingkatkan jumlahnya agar Bank BNI Syariah mencapai efisiensi yang sempurna. Sehingga selain analisis tingkat efisiensi 
secara general, diperlukan juga analisis efisiensi pada variabel input dan output Bank BNI Syariah.

Variabel input dan output memiliki score efisiensi per variabel yang membentuk efisiensi suatu DMU secara keseluruhan. Jumlah dari suatu variabel yang efisien ditunjukkan dengan angka aktual dan angka proyeksi pada analsisis variabel(Susilowati dkk, 2004). Angka aktual adalah angka input dan output yang dimiliki oleh DMU, sedangkan angka proyeksi adalah angka yang bisa dicapai oleh DMU dari perhitungan DEA (Nadiak dkk, 2015).

Hasil efisiensi variabel menunjukkan variabel-variabel yang menyebabkan inefisiensi pada kinerja Bank BNI Syariah. Variabel input ouput yang menentukan tingkat inefisiensi Bank BNI Syariah pada model CRS yang berorientasi input adalah seluruh variabel pada sisi input dan total pembiayaan dan pendapatan operasional lain pada sisi output. Pada sisi input, DPK menjadi penyebab terbesar inefisiensi Bank BNI Syariah, di mana jumlah DPK harus dikurangi sebesar Rp2.368.724.000. Sedangkan pada sisi output adalah total pembiayaan yang harus ditingkatkan sebesar Rp5.615.731.000. Kemudian untuk orientasi output pada model CRS, Variabel input ouput yang menentukan tingkat inefisiensi Bank BNI Syariah adalah biaya operasional lain pada sisi input dan seluruh variabel pada sisi output. Pada sisi output, total pembiayaan menjadi penyebab terbesar inefisiensi Bank BNI Syariah, di mana jumlah total pembiayaan harus ditingkatkan sebesar Rp7.962.826.000.

Variabel input ouput yang menentukan tingkat inefisiensi Bank BNI Syariah pada model VRS yang berorientasi input adalah seluruh variabel pada sisi input dan total pembiayaan dan pendapatan operasional lain pada sisi output. Pada sisi input, DPK menjadi penyebab terbesar inefisiensi Bank BNI Syariah, di mana jumlah DPK harus dikurangi sebesar Rp2.131.567.000. Sedangkan pada sisi output adalah total pembiayaan yang harus ditingkatkan sebesar Rp1.269.796.000. Kemudian untuk orientasi output pada model VRS, Variabel input ouput yang menentukan tingkat inefisiensi Bank BNI Syariah adalah biaya operasional lain pada sisi input dan seluruh variabel pada sisi output. Pada sisi output, total pembiayaan menjadi penyebab terbesar inefisiensi Bank BNI Syariah, di mana jumlah total pembiayaan harus ditingkatkan sebesar Rp3.958.286.000.

Berdasarkan hasil efisiensi variabel secara keseluruhan, maka dapat disimpulkan bahwa perhitungan efisiensi yang berorientasi input menunjukkan variabel DPK dari sisi input dan variabel total pembiayaan dari sisi output merupakan variabel-variabel yang sangat berpengaruh terhadap inefisiensi Bank BNI Syariah. Sedangkan pada orientasi output, variabel biaya operasional lain pada sisi input dan total pembiayaan pada sisi output merupakan variabel-variabel yang 
Nurfajina, et al/Jurnal Ekonomi Syariah Teori dan Terapan Vol. 6 No. 12 Desember 2019: 2435-2450; EFISIENSI KERJA SAMA PENJAMINAN PEMBIAYAAN BANK SYARIAH DI LEMBAGA PENJAMINAN SYARIAH

sangat berpengaruh terhadap inefisiensi Bank BNI Syariah. Oleh karena itu Bank BNI Syariah harus lebih baik lagi dalam mengatur kinerja kedua variabel tersebut agar selalu berada tingkat yang optimal atau efisien. kemudian variabel aktiva tetap adalah variabel yang paling tidak mempengaruhi inefisiensi Bank BNI Syariah, baik pada orientasi input maupun output.

Melihat hasil perhitungan dari keempat mitra bank syariah yakni Bank Syariah Mandiri, Bank BRISyariah, Bank BNI Syariah, dan BJB Syariah maka dapat disimpulkan bahwa Bank Syariah Mandiri, Bank BRISyariah, dan BJB Syariah menunjukkan nilai yang efisien, sedangkan Bank BNI Syariah menunjukkan inefisiensi. Artinya kinerja Bank Syariah Mandiri, Bank BRISyariah, dan BJB Syariah sudah berjalan dengan optimal, sedangkan kinerja Bank BNI Syariah bisa dikatakan kurang baik karena tidak berjalan dengan optimal. Meskipun kinerja Bank BNI Syariah kurang baik bukan berarti kontrak kerja sama dengan Bank BNI Syariah langsung diputuskan lewat inhilal (pembubaran), yang dimaksud pembubaran disini adalah penghentian dari kontrak kerjasama yang sah.

Sebagaimana yang telah dikemukakan oleh Dewi dkk, (2005:94-95) pada bab sebelumnya, dalam Islam kontrak kerjasama dipandang sebagai komitmen yang seharusnya melekat pada para pihak yang terlibat. Menjaga kontrak kerjasama merupakan suatu keharusan bagi mereka yang terlibat didalamnya.
Apalagi dalam Islam menyatakan bahwa pembubaran kontrak dapat dilakukan apabila hanya ada permasalahan yang serius dan dapat dilakukan pembubaran dengan syarat tidak terpenuhinya komitmen oleh salah satu pihak yang bersepakat.

Sedangkan inefisien pada Bank BNI Syariah bukanlah faktor sengaja dari pihak Bank BNI Syariah dan pihak Bank BNI Syariah bukanlah pihak yang gagal dalam memenuhi komitmen dalam perjanjian kerjasama penjaminan pembiayaan. Ini berarti langkah tepat yang dapat diambil oleh PT. Penjaminan Jamkrindo Syariah adalah bukan mengakhiri perjanjian kerjasama penjaminan pembiayaan, melainkan mengevaluasi pelaksanaan perjanjian kerjasama penjaminan pembiayaan seperti yang tertera pada PKS induk penjaminan pembiayaan antara PT. Penjaminan Jamkrindo Syariah dengan mitra bank syariah.

Kemudian karena Bank Syariah Mandiri, Bank BRISyariah, dan BJB Syariah telah menunjukkan kinerja yang efsisien maka perjanjian kerjasama penjaminan dengan ketiga bank tersebut dipandang tidak perlu untuk melakukan evaluasi ulang kontrak kerjasama penjaminan pembiayaan. Tetapi PT. Penjaminan Jamkrindo Syariah cabang Surabaya tetap menjaga hubungan baik dengan memberikan pelayanan yang terbaik. Hal itu dilakukan agar pelaksanaan kerja sama diantara dua pihak berjalan lancar dan mudah dalam menyelesaikan 
permasalahan jika terjadi hal-hal yang tidak diinginkan di masa yang akan datang,

\section{SIMPULAN}

Secara umum, pelaksanaan kerja sama penjaminan pembiayaan dengan bank syariah di PT. Penjaminan Jamkrindo Syariah cabang Surabaya sudah berjalan dengan cukup baik, entah dari mekanisme Conditional Automatic Cover (CAC) ataupun mekanisme Case by Case $(C B C)$. Dikatakan cukup baik karena dalam praktiknya, masih ada beberapa hal yang belum sesuai sepenuhnya dengan fatwa Dewan Syariah Nasional Majelis (DSN) MUI No. 74/DSN-MUI/I/2009. Peraturan Otoritas Jasa Keuangan (OJK) No. 06/POJK.05/2014 telah diterapkan sebagai pedoman pelaksanaan penjaminan syariah yang dimuat dalam SOP Penyusunan Perjanjian Kerja Sama PT. Penjaminan Jamkrindo Syariah cabang Surabaya. Walaupun tahapan pelaksanaan kerja sama penjaminan sudah tercakup dalam SOP, tetapi masih saja ada beberapa tahapan yang tidak dilakukan dengan tepat oleh bank syariah.

\section{Pelaksanaan} kerjasama penjaminan pembiayaan di PT. Penjaminan Jamkrindo Syariah cabang Surabaya dengan Bank BNI Syariah perlu dievaluasi kembali. Hal ini dikarenakan uji efisiensi Bank BNI Syariah dengan software MaxDEA Basic 7 menunjukkan hasil inefisien, yang berarti Bank BNI Syariah perlu meningkatkan lagi kinerjanya.
Sedangkan Bank Bank Syariah Mandiri, Bank BRISyariah, dan Bank BJB Syariah menunjukkan hasil yang telah efisien, artinya kinerja ketiga bank tersebut telah berjalan dengan optimal. Pengukuran kinerja mitra bisnis ini penting dilakukan mengingat kerjasama penjaminan pembiayaan merupakan salah satu kegiatan utama bisnis PT. Penjaminan Jamkrindo Syariah cabang Surabaya.

\section{DAFTAR PUSTAKA}

Ascarya and Yumanita, Diana (2006). Analisis Efisiensi Perbankan Syariah di Indonesia dengan Data Envelopment Analysis. TAZKIA Islamic Finance and Business Review, 1 (2).

Ascarya, Diana Yumanita, Guruh $S$. Rokhimah (2009). Analisis Efisiensi Perbankan Konvensional dan Perbankan Syariah di Indonesia Dengan Data Envelopment Analysis. dalam Current Issues Lembaga Kevangan Syariah, editor Nurul Huda dan Mustofa Edwin Nasution, Jakarta: Prenada Media Group.

Berger, Allen N., Humphrey, David B (2006). Efficiency of Financial Institutions: International Survey and Directions for Future Research. General Council for Islamic Banks and Financial Institutions. CIBAFI Performance Indicators, CIBAFI.

DSN-MUI No. 11/DSN-MUI/IV/2000 tentang Kafalah 
Nurfajina, et al/Jurnal Ekonomi Syariah Teori dan Terapan Vol. 6 No. 12 Desember 2019: 2435-2450; EFISIENSI KERJA SAMA PENJAMINAN PEMBIAYAAN BANK SYARIAH DI LEMBAGA PENJAMINAN SYARIAH

DSN-MUI No. 74/DSN-MUI/I/2009 tentang Penjaminan Syariah

DSN-MUI No. 43/DSN-MUI/VIII/2004 tentang Ganti Rugi (ta'widh)

Hadad, Muliaman D., et al. (2003). Analisis Efisiensi Industri Perbankan Indonesia: Penggunaan Metode Nonparametrik Data Envelopment Analysis (DEA). Biro Stabilitas Sistem Kevangan Bank Indonesia, Research Paper, 7 (5).

Hermansyah (2009). Hukum Perbankan Nasional Indonesia. Edisi Revisi. Jakarta: Kencana.

Kamaruddin, Dkk. (2008). Asseing Production Efficiency Of Islamic Banks And Conventional Bank Islamic Windows In Malaysia.International Journal Of Business And Management Science, 1(1): 31-48.

Mardani (2012). Fiqh Ekonomi Syariah; Fiqh Muamalah, (Cetakan Ke-4). Jakarta: Kencana.

Moleong, Lexy J. (2004). Metodologi Penelitian Kualitatif. Bandung: PT. Remaja Rosdakarya

Muharam. H dan Pusvitasari. R. (2007). Analisis Perbandingan Efisiensi Bank Syariah di Indonesia dengan Metode Data Envelopment Analysis (Periode Tahun 2005). Jurnal Ekonomi dan Bisnis Islami, 2 (3).

Muhammad (2004). Manajemen Dana Bank Syariah. Yogyakarta: EKONISIA.
Mujahidin, Akhmad (2016). Hukum Perbankan Syariah. Jakarta: Rajawali Pers.

OJK No. 6/POJK.05/2014 tentang Penyelenggaraan Usaha Lembaga Penjaminan

OJK No. 2/POJK.05/2017 tentang Penyelenggaraan Usaha Lembaga Penjaminan

Puspita, Hilda Sukma Dan Shofawati A (2018). Determinan Tingkat Efisiensi Bank Pembangunan Daerah (Bpd) Syariah di Indonesia: Two-Stage Data Envelopment Analysis. Jurnal Ekonomi Syariah Teori dan Terapan, 5 (10).

Putri, Linda D.W. dan Shofawati A (2018). Efisiensi Bank Umum Syariah dan Unit Usaha Syariah di Indonesia Tahun 2012-2016 Metode Non Parametrik. Jurnal Ekonomi Syariah Teori dan Terapan, 5 (9).

Rochmanika, Ridha Dan Aulia, F. Rahman (2012). Pengaruh Pembiayaan Jual Beli, Pembiayaan Bagi Hasil, Dan Rasio Non Performing Financing Terhadap Profitabilitas Bank Umum Syariah Di Indonesia. Iqtishoduna.

Rose, Peter.S. (1999). Commercial Bank Management. Fourth edition. USA: Mc.Graw Hill International Edition.

Saputra, R. (2018). Efisiensi Universitas Badan Layanan Umum dengan Metode Data Envelopment Analysis. Indonesian Treasury Review: Jurnal Perbendaharaan, 
Keuangan Negara Dan Kebijakan

Publik, 3(1): 35-42.

Siamat, Dahlan (2004). Manajemen Lembaga Kevangan: Edisi keempat. Jakarta: Lembaga Penerbitan Fakultas Ekonomi Universitas Indonesia.

Sjahdeini, Sutan Remy (2014). Perbankan Syariah; Produk-Produk Dan AspekAspek Hukumnya. Cetakan Ke-2. Jakarta: Kencana.

Sofyan, Sofriza (2003). Pengaruh Struktur Pasar Terhadap Kinerja Perbankan Di Indonesia. Media Riset Bisnis \& Manajemen, 2 (3): 194-219.

Suhada (2009). Analisis Perbandingan Kinerja Kevangan Bank Syariah Dan Bank Konvensioal Periode 2003-2007.Jurnal Ekonomi Bisnis,

Suma, M. Amin (2006). Asuransi Syariah dan Asuransi Konvensional. Jakarta: Kholam Publishing.

Susanto, Burhanuddin (2008). Hukum Perbankan Syariah di Indonesia, Jogjakarta: UII Press.
Susilowati, Indah. (2004). Modul Perkuliahan Pengukuran Efisiensi melalui Data Envelopment Analysis (DEA). Semarang: FE UNDIP

Tanjung, Hendri dan Devi A. (2013). Metodologi Penelitian Ekonomi Islam. Jakarta: Gramata Publishing.

Usanti, T. Prasastinah (2012). Pengelolaan Risiko Pembiayaan Di Bank Syariah. Jurnal Hukum: Adil, 3 (2).

Wibowo, E. Satriyo \& Syaichu, M. (2013). Analisis Pengaruh Suku Bunga. Inflasi, CAR, BOPO, NPF Terhadap Profitabilitas Bank Syariah. Diponegoro Journal Of Management, 2 (2): 1-10.

Yazid, Muhammad (2014). Hukum Ekonomi Islam: Fiqh Muamalah. Surabaya: UIN Sunan Ampel Press.

Yudistira, Donsyah (2003). Efficiency in Islamic Banking; An Empirical Analysis of 18 Banks. Paper, Loughborough University, United Kingdom. 